\title{
Erratum to: Forward Higgs production within high energy factorization in the heavy quark limit at next-to-leading order accuracy
}

\author{
M. Hentschinski ${ }^{1}$ K. Kutak $^{2, a}$, A. van Hameren ${ }^{2}$ \\ ${ }^{1}$ Departamento de Actuaria, Física y Matemáticas, Universidad de las Americas Puebla, Santa Catarina Martir, 72820 Puebla, Mexico \\ ${ }^{2}$ Institute of Nuclear Physics, Polish Academy of Sciences, ul. Radzikowskiego 152, 31-342 Kraków, Poland
}

Published online: 26 March 2021

(C) The Author(s) 2021

Erratum to: Eur. Phys. J. C (2021) 81:112

https://doi.org/10.1140/epjc/s10052-021-08902-6

In the original article, the following equations were incorrect: Equations 8, 9, 12, 56, 62, 66 and 68

An additional symbol " $\times$ " had been introduced during the typesetting process.

The original article has been corrected.

The original article can be found online at https://doi.org/10.1140/ epjc/s10052-021-08902-6.

\footnotetext{
a e-mail: krzysztof.kutak@ifj.edu.pl (corresponding author)
}

Open Access This article is licensed under a Creative Commons Attribution 4.0 International License, which permits use, sharing, adaptation, distribution and reproduction in any medium or format, as long as you give appropriate credit to the original author(s) and the source, provide a link to the Creative Commons licence, and indicate if changes were made. The images or other third party material in this article are included in the article's Creative Commons licence, unless indicated otherwise in a credit line to the material. If material is not included in the article's Creative Commons licence and your intended use is not permitted by statutory regulation or exceeds the permitted use, you will need to obtain permission directly from the copyright holder. To view a copy of this licence, visit http://creativecomm ons.org/licenses/by/4.0/.

Funded by $\mathrm{SCOAP}^{3}$. 